\title{
Biotreatment of Brewary Effluent Using Pseudomonas Species
}

\author{
Rajashekar Bodike ${ }^{1}$, Sandhya Rani Thatikonda ${ }^{2}$ \\ ${ }^{1}$ Master of Science in Cellular and Molecular Biotechnology University of Trento, Italy \\ ${ }^{2}$ Master of Technology in BiotechnologySree Nidhi Institute of Science and Technology
}

\begin{abstract}
During the last two decades the brewing industry has shown increasing awareness for environmental protection and the need of sustainable production processes.

Implementation of ISO 14001 certification and more stringent environmental legislation have been important drivers for the brewing industry to invest in biological effluent treatment.

The project work was carried with the objective of treating wastewater coming from the brewery effluent was treated with Pseudomonas species over a period of time. The results indicate substantial changes in the effluent. The $\mathrm{pH}$ and color of the effluent was found to reduce drastically from higher $\mathrm{pH}$ to lower $\mathrm{pH}$ i.e. 10.2 to 8.67 and the color from dark black to black. The Pseudomonas on inoculation further reduced the carbohydrate and protein concentration by $56 \%$ and $25 \%$ respectively. The other components like salts and ammonia were reduced considerably.

This particular study further proves the importance of microorganisms in bioremediation of brewery effluent. Based on the socio-economics criteria the anaerobic pretreatment can be combined with aerobic biological post treatment thereby, integrating the advantages of both the processes like reduced energy consumption (net energy production), reduced biological sludge production and limited space requirement. The combination allows for significant savings on operational costs as compared to complete aerobic treatment without comprising the required discharge standards.
\end{abstract}

Key words: Anaerobic,Bioremediation,Carbohydrate, Colour, Inoculation, Pseudomonasspecies, Protein.

\section{Introduction:}

Beer brewing processes require large amounts of water, it is widely estimated that for production of 1 liter of beer it requires close to 10 liters of water mostly for brewing, rinsing, and cooling processes. so these brewing processes are generating large amounts of waste water effluent and solid waste that has to be disposed off, or treated in less costly and safety way to protect life and environment. for such purposes a waste water treatment plant that maximizes the efficiency and minimizes the investment and operation cost is a key factor.

\subsection{Composition of Brewery Effluent:}

The quality and quantity of brewery effluent can fluctuate significantly as it depends on various processes that take place within the brewery such as raw material handling, wort preparation, fermentation, filtration, CIP, packaging. Etc. but the amount of waste water produced depends on the amount of water consumed during the process. In general,water consumption per volume of produced beer attain $4.7 \mathrm{~m}^{3} / \mathrm{m}^{3}$ (Carlsberg,2005) but it should be pointed that the waste water to beer ratio is often $1.2-2 \mathrm{~m}^{3} / \mathrm{m}^{3}$ less because part of water is disposed off with by-products and lost by evoparation (Drissen and vereijken,2003).

Organic components in brewery effluent (expressed as COD) are generally easily biodegradable as these mainly consist of sugars, soluble starch, ethanol, volatile fatty acids, etc. This is illustrated by the relatively high $\mathrm{BOD} / \mathrm{COD}$ ratio of 0.6-0.7.The brewery solids (expressed as TSS) mainly consist of spent grains, kieselguhr, waste yeast and ('hot')trub.Brewery effluent $\mathrm{pH}$ levels are mostly determined by the amount and type of chemicals used at the CIP units (e.g. caustic soda, phosphoric acid, nitric acid etc). Nitrogen and phosphorous levels are mainly depending on the handling of raw material and the amount of result of phosphorous containing chemicals used in the CIP unit[3].

\begin{tabular}{|l|l|l|l|}
\hline PARAMETER: & UNIT: & $\begin{array}{l}\text { BREWERY EFFLUENT } \\
\text { COMPOSTION: }\end{array}$ & $\begin{array}{l}\text { TYPICAL BRWERY BENCH } \\
\text { MARKS: }\end{array}$ \\
\hline Flow & - & - & $2-8 \mathrm{hl} \mathrm{effluent/hl} \mathrm{beer}$ \\
\hline COD & $\mathrm{mg} / \mathrm{l}$ & $2000-6000$ & $0.5-3 \mathrm{~kg}$ COD/hl beer \\
\hline BOD & $\mathrm{mg} / \mathrm{l}$ & $1200-3600$ & $0.2-2 \mathrm{~kg} \mathrm{BOD} / \mathrm{hl}$ beer \\
\hline TSS & $\mathrm{mg} / \mathrm{l}$ & $200-1000$ & $0.1-0.5 \mathrm{~kg}$ TSS/hl beer \\
\hline Temperature & $\mathrm{C}$ & $18-40$ & - \\
\hline pH & - & $4.5-12$ & - \\
\hline Nitrogen & $\mathrm{mg} / \mathrm{l} \mathrm{mg} / \mathrm{l}$ & \multicolumn{1}{|c|}{$10-50$} & - \\
\hline Phosphorous & \multicolumn{1}{|c|}{$\mathrm{m}$} & - \\
\hline
\end{tabular}

Table 1: Typical characteristics of brewery effluent 
Removal of organic compounds (COD chemical oxygen demand) from the wastewater is important to avoid anaerobic conditions in the receiving waters. Nutrients like nitrogen $(\mathrm{N})$ and phosphorous $(\mathrm{P})$ should be removed to avoid algae bloom disturbing the receiving waters ecosystem[3].

To achieve this, in this project we preferred an eco-friendly bioremediation process. Prescott et al; (2002) defined bioremediation as the use of micro organisms to remove pollutants from the environment. Bioremediation has rapidly become the technology of choice for remediation of contaminated water constituent. In this study an aerobic treatment system was preferred to attain high efficiency of removal of COD and nuetrients than anaerobic treatment. $70-85 \%$ of COD can be removed by using an anaerobic treatment, whereas, by aerobic system $90-98 \%$ of COD can be removed Bacteria associated with brewery operations include Flavobacterium spp, Proteus spp, Escherichia spp, Klebsiella spp, Lactobacillus spp and acetic acid bacteria such as Guconobacter spp and Acetobacterispp[4].

+1.2 Pseudomonas is one of the most preferred bacteria for brewery treatment; because it is a Gram-negative, Slightly motile, polysaccharide based capsule bacteria, easily growing and not harmful. This allows the effluent discharges into surface waterbodies. In this study intrinsic bioremediation has been employed to degrade brewery effluent using bacteria indigenous to the effluent.

\section{Objectives}

The research work is to practice of utilizing microorganisms to carryout chemical transformation has been applied in proving brewery and dairy industries.

In this case microorganisms are play vital role to treat critical components in brewery and dairy industries.in this treatment of waste water microorganisms use this organic matter in the waste stream as a good source. The bacteria consume the organic matter and convert them into $\mathrm{Co}_{2}$, water and energy to produce new cells. Ultimately the soluble pollutants are converted into soluble biomass, which can be removed mechanically from waste stream and sent to disposal.

In many countries around the world breweries still discharge untreated waste water and yeast directly into river and seas and unused spent grains are dumped.so our research project is designed to make an attempt for the biodegradation of organic pollutant present in the brewery waste by using Pseudomonas sps. In this case Pseudomonas sps are known for bioremediation of different kinds of industrial waste.

The treatment of effluent can be done with physic chemical methods as well but the bio treatment technologies using a wide variety of bacteria fungi has a lot of advantages when compared to the chemical methods.

The bioremediation, bio augmentation methods are cost effective and can be used insitu without causing damage to the environment.

The scope of bio augmentation technology is simply enormous for a safe way towards clean environment.

\subsection{APPARATUS AND EQUIPMENTS USED:}

\section{Materials And Methods}

Glassware(Borosil),PHmeter(Essel),Photocolorimeter (EI),LaminarAirflow(AirconMumbai),Autoclave (Robot),Micropipette (Basco),Microscopes(Blisco)

3.1.1 INDUSTRIAL WASTE Water: Brewery effluent. CHEMICALS FOR BACTERIA ISOLATION MEDIA:

3.1.2 NUTRIENT AGAR MEDIUM:Components are Peptone - 0.5, Beef Extract -0.5,Nacl -0.3, Agar-1, Distill water -100, pH - 6-7

\subsubsection{DNS CHEMICALS:Sodium Potassium Tartarate,3-5- Di-nitro salicylate, $\mathrm{NaOH}$}

\subsubsection{LOWRY'S CHEMICALS:BSA ( Bovine Serum Albumin) Solution, Alkaline CuSo4,Folin's-cio-calteau Reagent}

3.1.5 CHLORIDE'S CHEMICALS:Silver Chloride, SilverNitrate, Potassium Chromate 3.1.6 AMMONIA CHEMICALS:Phenol Nitroprusside solution, Alkaline Hypochlorite solution

\subsection{METHODS}

\subsubsection{ISOLATION OF BACTERIA:}

1. Prepared isolation medium is poured into the plates and allowed to solidify.

2. Brewery effluent (sample) is collected from the beer industries.

$3.5 \mathrm{ml}$ of the sample is added to $45 \mathrm{ml}$ of distilled water.

4. Then $0.1 \mathrm{ml}$ of above sample mixture is plated on isolation medium by Spread Plate Technique.

5. The plates are kept for incubation at $37^{\circ} \mathrm{C}$ for overnight. 
6. After 24 hours, the bacterial growth is observed.

7. The colonies are observed under the microscope by Gram Staining Technique.

8. Finally these colonies are sub-cultured by Streak Plate Technique.

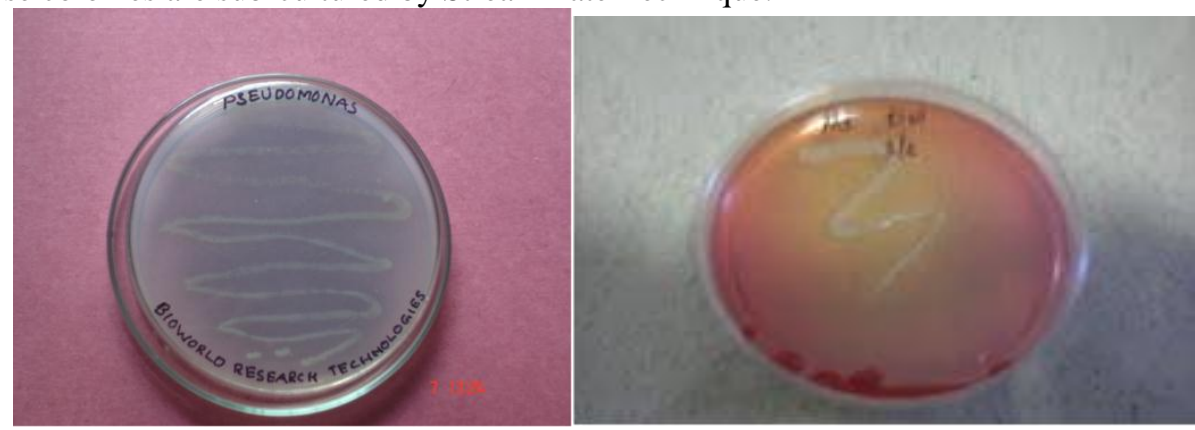

Fig 1 Pseudomonas grown on nutrient medium

TESTS FOR IDENTIFICATION OF PSEUDOMONAS SPECIES

3.2.2 PSUEDOMONAS: The Pseudomonas colonies were Blue green in color, Gram negative,

Rod shaped bacillus, Does not give any of the IMVIC reactions, Lactose $=$ negative

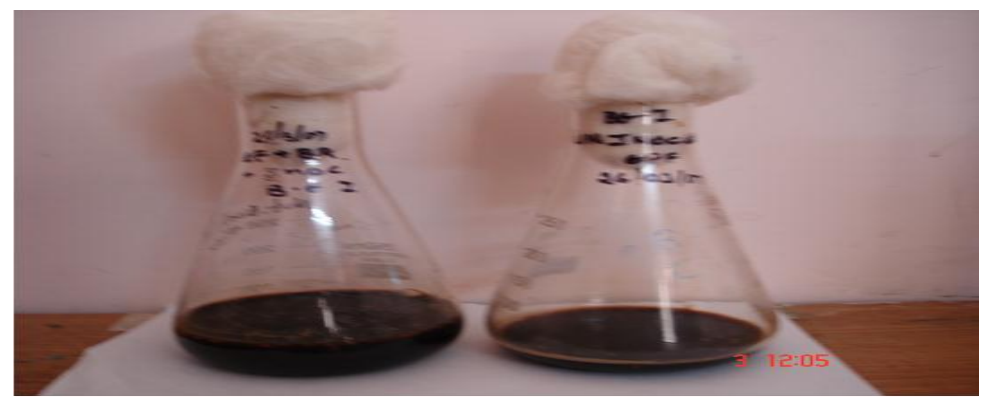

Fig 2 Test and samples of brewery for testing

\section{BIOCHEMICAL TESTS (IMVIC TESTS)}

3.2.3 INDOLE TEST:The isolate was inoculated into test tubes separately into Tryptophan or peptone Broth. And incubated at $37^{\circ} \mathrm{C}$ for $24 \mathrm{hrs}$. After incubation Kovac's reagent was added to both the test tubes. The positive reaction is indicated by change of colorof Kovac's reagent to red

RESULT: The isolate was found to be negative for indole test.

3.2.4 Methyl red test:Both the isolates are inoculated separately into test tubes containing MRVP medium.(Composition of Methylred-VogusprosKauer's medium is glucose phosphate, water, Peptone, Dextrose, distilled water, $\mathrm{pH}-7.5)$. and they are incubated at 37deg.C for 24-48 hrs. After incubation add 1-2 drops of methyl red indicator, and 2-3 drops of reagent was added and shaken thoroughly. It was then allowed to react for 15-30minutes. The colour change to red indicates positive for methyl red and colourless indicates positive for voges-proskauer test Methyl red indicator is Methyl red, Absolute Alcohol, dist. Water. If the test is positive the medium with culture turns red which infers that the organism is a mixed acid fermentor.

RESULT:The isolate found to be negative for Methyl red test.

3.2.5 Voges -Proskauertest :The isolate was incubated seperately into test tubes containing MRVP medium. The composition is Peptone, cellulose or dextrose, Dipotassium hydrogen phosphate dist. Water, at a $\mathrm{pH}$ of 7.5. Then they are incubated at $37^{\circ} \mathrm{C}$ for $48 \mathrm{hrs}$. To the inoculate $40 \% \mathrm{KOH}$ and of $5 \%$ Alpha-naphthol (Barrods reagent) is added and shaken well, allowed it to stand for 2 minutes. A positive test involves production of pink colour in the Medium, which indicates that the organism has fermented glucose and produced acetone.

RESULT:The isolate showed negative test for Vogusproskauer test.

3.2.6 CITRATE UTILISATION TEST:Two agar slants of Kosser's citrate agar medium were prepared. Kosser's medium consist of sodium ammonium phosphate, Dipotassium hydrogen phosphate, Bromomethylblue blue, Sodium citrate, dist. Water. The isolate was inoculated on to slants and incubated at 37 deg. C for $24 \mathrm{hrs}$. Citrate utilization is indicated by growth and change in colour of the medium from green to blue. 
RESULT:The isolate showed positive test for citrate utilization test.

\subsection{ESTIMATIONS:}

\subsubsection{ESTIMATION OF CARBOHYDRATE BY DNS REAGENT:}

AIM: To estimate for glucose (reducing sugar) present in the given sample and construct a standard graph using known concentration of glucose.

PRINCIPLE: Glucose is a reducing sugar because of free Aldehyde group present in the basic structure so it reduces 3,5-DNS to 3- Amino-5-Nitro salicylic Acid which can be seen as orange-red complex whose intensity is measured calorimetrically at $540 \mathrm{~nm}$.

PROCEDURE: Various aliquots of glucose standard are taken into different test tubes such as $0.1,0.2,0.4,0.6$, 0.8 and $1 \mathrm{ml}$ and make the volume to $1 \mathrm{ml}$ by adding distill water, then add $2 \mathrm{ml}$ of DNS solution and vortex the sample. Incubate the test tubes in boiling water bath for 10 minutes till the orange-red complex is formed. Cool the samples and add $7 \mathrm{ml}$ of distill water. Take OD values at $540 \mathrm{nms}$. Repeat the same procedure fro test sample and blank using test solution and water respectively.

\subsubsection{ESTIMATION OF CHLORIDE:}

AIM: Natural water normally has a low chloride contents compared to bicarbonates ( HCO3) \&sulphonates ( $\mathrm{SO} 4)$. High chloride (C1) are found in inland saline lakes, estuaries \& marine waters. High chloride level indicates pollution from domestic sewage \& industrial effluents. Though chlorides level as high as $250 \mathrm{mg} / \mathrm{l}$ is safe for human consumption, a level above this imparts a salty taste to the potable water.

PRINCIPLE: The chlorides are estimated by precipitating chloride ions in water as silver chloride $(\mathrm{AgCl})$ by titrating against $0.02 \mathrm{~N}$ silver nitrate ( $\mathrm{AgNo} 3$ ) with potassium chromate ( $\mathrm{K} 2 \mathrm{Cr} 2 \mathrm{O} 4)$ as indicator .

PROCEDURE: Into $10 \mathrm{ml}$ sample add few drops of ( $\mathrm{K} 2 \mathrm{Cr} 2 \mathrm{O} 4)$. Titrate the sample against $0.02 \mathrm{~N}$ AgNo3 .end point - yellow to brick red

\subsubsection{ESTIMATION OF AMMONIA:}

AIM: Two main sources of this highly toxic waste products are decomposition of organic matter and excretory products of aminotelicorganisms .

PRINCIPLE: Ammonia dissolves in water to form ammonium hydroxide that further dissociates into ammonium and hydroxyl ions as follows:-

$$
\mathrm{NH} 3+\mathrm{H} 20 \rightarrow \mathrm{NH}^{4} \mathrm{OH} \rightarrow \mathrm{NH} 4+\mathrm{OH}
$$

Aquatic autotrophs incorporate nitrogen through ammonium ions at a faster rate .

PROCEDURE: Different aliquots of ammonium standard are taken into different test tubes as $0.1,0.2,0.4$, $0.6,0.8$ and $1 \mathrm{ml}$. Into each sample and $2 \mathrm{ml}$ of phenol nitroprusside solution and add $2 \mathrm{ml}$ of alkaline hypochlorite solution. Make up total volume to $1 \mathrm{ml}$ by adding ammonia free distill water. Keep the sample in dark place for one hour at $25^{\circ} \mathrm{c}$ after which measure the absorbance at $635 \mathrm{~nm}$ on a spectrophotometer. Read value of ammonia as ammonium N/L from the standard graph. Repeat the procedure with test sample and check the absorbance on standard graph.

\section{Results And Discussion:}

Brewery effluent was collected various breweries in and around nacharam industrial area in Hyderabad, Andrapradesh, India. The sample was found to be viscous, dark black color with a $\mathrm{pH}$ of 10.2 the effluent sample was plated on to nutrient agar and incubated for 3-5 days. The plates show different types of colonies. Pseudomonas was found in almost all the plates. The isolate was further inoculated into sterile brewery effluent and further evaluated for change in various components and parameters. The obtained results are given below in table

Table 2 showing results obtained after 5-15 days of incubation of brewery effluent

\begin{tabular}{|l|c|c|c|c|}
\hline Parameters & Uninoculated sample & Day5 & Day10 & Day 15 \\
\hline $\mathrm{pH}$ & 10.2 & 9.1 & 8.67 & 8.66 \\
\hline Colour & Dark Black & Dark Black & Black & Black \\
\hline Temperature $\left({ }^{\circ} \mathrm{c}\right)$ & 30 & 30 & 30 & 30 \\
\hline Carbohydrate $(\mu \mathrm{g} / \mathrm{ml})$ & 2020 & 1845 & 940 & 938 \\
\hline Protein $(\mu \mathrm{g} / \mathrm{ml})$ & 1880 & 1563 & 1360 & 1355 \\
\hline Chlorides $(\mathrm{mg} / \mathrm{ml})$ & 141.8 & 113.5 & 85.08 & 84.04 \\
\hline Ammonia $(\mu \mathrm{g} / \mathrm{ml})$ & 846.3 & 726.2 & 519.6 & 516.4 \\
\hline
\end{tabular}


Pseudomonas is inoculated into brewery effluent water and monitored for 5-15 days for the bioremediation of brewery effluent. Based on the results obtained with the brewery wastewater bio-treatment experiments, the above bacterium was capable of growing and degrading the pollutants in the feeding effluent.

Resident microbial consortia detected and isolated during brewery wastewater bio-treatments revealed a predominance of bacterial species, belonging to the genera Bacillus and Pseudomonas, and a total absence of filamentous fungi. One feature of these species must be their resistance to the extreme conditions.

Our studies show that the organism is able to tolerate high concentration of carbohydrates and proteins present in the sample and is able to reduce them upto $54 \%$ and $25 \%$ respectively.

One feature of the organism is that it is even active at very high $\mathrm{pH}$ and is able to lower the $\mathrm{pH}$ from 10.2 to 8.67 .

The ability of the organism is further evaluated by inoculating into brewery effluent, where it reduced the concentration of other effluents like chloride, and ammonia present in the sample.

This study proves the efficacy of Pseudomonas in treatment of brewery effluent in short span of time and which can be utilized for bioremediation of other food industry effluents.

\section{Conclusion}

Pseudomonas is inoculated into brewery effluent water and monitored for 5- 15 days for the bioremediation of brewery effluent. Based on the results obtained with the brewery wastewater bio-treatment experiments, the above bacterium was capable of growing and degrading the pollutants in the feeding effluent. Resident microbial consortia detected and isolated during brewery wastewater bio-treatments revealed a predominance of bacterial species, belonging to the genera Bacillus and Pseudomonas, and a total absence of filamentous fungi. One feature of these species must be their resistance to the extreme conditions.

Our studies show that the organism is able to tolerate high concentration of carbohydrates and proteins present in the sample and is able to reduce them up to $54 \%$ and $25 \%$ respectively.

One feature of the organism is that it is even active at very high $\mathrm{pH}$ and is able to lower the $\mathrm{pH}$ from 10.2 to 8.67 .

The ability of the organism is further evaluated by inoculating into brewery effluent, where it reduced the concentration of other effluents like chloride, and ammonia present in the sample.

This study proves the efficacy of Pseudomonas in treatment of brewery effluent in short span of time and which can be utilized for bioremediation of other food industry effluents.

\section{Acknowledgment}

Starting with millions of thanks to GOD, the Omnipotent and who is so kind to mankind and who enabled me for successfully completing this internship research and report. Special thanks To my Friend Sandhya Rani for their kind help in my experiment's data collection and Paper completion. I am extremely thankful to my Project guide Sreenivas for their sincere and kind help throughout my research work.

Last but not the least; I express my deepest appreciation and recognition to my parents, brothers and sister, who Supported me morally and financially throughout my educational carrier.

\section{References}

[1]. Barker, A.J., Stocks, C. and Guy, S., Options for the disposal of brewery effluents. Proceedings of the 7th Brewing Convention, Inst. Brew. Africa Sect. Nairobi, Kenya, 1999, pp. 186-192.

[2]. Craft, C.M. and Nelson, E.B., Microbial properties of composts that suppress damping off and root rot of creeping bent grass caused by Pythium graminicola. Appl. and Environ. Microbiol., 1996, 62(5), 1550-1557.

[3]. Genner, C., Treatment and disposal of brewery effluents. Brew-ers Guardian, 1988, Oct., 25-27.

[4]. Johnson, D., Underworld connections. Biologist, 2005, 52(3), 155-160.

[5]. Kanagachandran, K., Biogas generation from brewery wastes. Demonstration at a laboratory scale. Tech. Q. Master Brew. Assoc. Am., 2004, 41(4), 394-397.

[6]. Kanagachandran, K., Optimisation of spent grain slurry for en-ergy generation. Tech. Q. Master Brew. Assoc. Am., 2005, 42(4), 324-328.

[7]. Luque, O., Bracho, O. and Maier, T.W., Utilization of brewery waste water sludge for soil improvement. Tech. Q. Master Brew. Assoc. Am., 1990, 27(1), 5-9.

[8]. Reed, R. and Henderson, G., Water and waste water manage-ment. Its increasing importance to brewery and maltings pro-duction costs. Ferment, 1999, 12(6), 13-17.

[9]. Stocks, C., Barker, A. J. and Guy, S., The composting of brew-ery sludge. J. Inst. Brew. 2002, 108(4), 452-458.

[10]. Bitton G (2005). Wastewater Microbiology. 3rd Edition.Wiley-Liss Pub, ISBN 0-471-30985-0. pp. 55-72, 213-222, 502-518

[11]. Briggs DE, Boulton CA, Brooers PA, Stevens R (2004). Brewing science and practice. CRC press, ISBN 0-8493-2547-1. p. 36

[12]. Holt JG, Krieg NR, Sneath PHA, Staley JT, Williams ST (1994). Bergey's Manual of Determinative Bacteriology. 9th, Baltimore; the Williams Wilkins Co., (ISBN 0-683-00603-7). p. 78 